\author{
Лiсус Oльга Марківна \\ кандидат мистечтвознавства, \\ Київський національний університет \\ культури і мистецте \\ Kü̈s, Укpä̈на \\ olga-ligus@ukr.net
}

\title{
ТЕОРЕТИЧНІ АСПЕКТИ СПВВІДНОШЕННЯ МУЗИЧНОГО СТИЛЮ І ЖАНРУ
}

Мета роботи. У статті розкривається характер співвідношення стилю та жанру - клочових категорій музичного мистецтва, які знаходяться у постійній взаємодії. Теоретичні аспекти цієї проблеми виокремлюються в роботі на підставі вивчення наукових праць XX-XXI ст., присвячених цим складним багаторівневим поняттям. Методологія дослідження базується на теоретичному методі систематизації, що полягас у пізнанні та осмисленні наукових теорій стилю i жанру. Цей метод, що має комплексний характер, охоплює низку інших методів, які використано в дослідженні, зокрема: абстрагування (у диференційованому розгляді понять стилю і жанру та виділенні найістотніших рис кожного з них); аналіз (у встановленні зв'язків між категоріями стилю і жанру); синтез (у розгляді стилю і жанру як компонентів ієрархічної системи музики). Крім того, в дослідженні застосовано й історичний метод (в розкритті характеру співвідношення стилю і жанру в процесі еволюції музичного мислення). Наукова новизна роботи полягає в порушенні проблеми співвідношення стилю і жанру, в окресленні ії основних теоретичних аспектів, у розвитку теоретичного дискурсу стиле-жанрової природи музичних явищ. Висновки. Доведено, що співвідношення стилю і жанру зумовлено логікою музичноісторичного процесу. Виділено основні теоретичні аспекти проблеми співвіднопення цих категорій: ієрархічну підпорядкованість жанру стилеві, діалогічний характер співіснування стилю і жанру, феномен жанрового стилю.

Ключові слова: стиль, жанр, співвідношення стилю i жанру, діалог стилю і жанру, жанровий стиль, епохальний стиль, індивідуальний стиль.

Лигус Ольга Марковна, кандидат искусствоведения, Киевский начиональньй университет культуры и искусств, Киев, Украина

Теоретические аспекты соотношения музыкального стиля и жанра 
Цель работы. В статье раскрывается характер соотношения стиля и жанра - ключевых категорий музыкального искусства, которые находятся в постоянном взаимодействии. Теоретические аспекты этой проблемы веделяются в работе на основе изучения научных исследований XX-XXI в.в., посвященных этим сложньм многоуровневым понятиям. Методология исследования базируется на теоретическом методе систематизации, который состоит в познании и осмыслении научных теорий стиля и жанра. Этот метод, имеющий комплексный характер, охватывает ряд других методов, использованных в данном исследовании, в частности: абстрагирование (в диференттцированном рассмотрении понятий стиля и жанра, а также, выделении наиболее существенных черт каждого из этих понятий); анализ (в установлении связей между категориями стиля и жанра); синтез (в рассмотрении стиля и жанра как компонентов иерархической системы музыки). Кроме того, в исследовании применен исторический метод (в раскрытии характера соотношения стиля и жанра в процессе эволюции музыкального мышления). Научная новизна работы состоит в постановке проблемы соотношения стиля и жанра, в определении ее основных теоретических аспектов, в развитии теоретического дискурса стиле-жанровой природы музыкальных явлений. Выводы. Доказано, что соотношение стиля и жанра обусловлено логикой музыкально-исторического процесса. Выделено основные теоретические аспекты проблемы соотношения стиля и жанра: иерархическую подчиненность жанра стилю, диалогический характер сосуществования стиля и жанра, феномен жанрового стиля.

Ключевые слова: стиль, жанр, соотношение стиля и жанра, диалог стиля и жанра, жанровый стиль, эпохальный стиль, индивидуальный стиль.

Lihus Olha, Candidate of Arts Study, Kyiv National University of Culture and Arts, Kyiv, Ukraine

\section{Theoretical aspects of musical style and genre correlation}

The purpose of the article is to determine the character of correlation between style and genre - the crucial categories of musical art, which are constantly interrelated. Theoretical aspects of this problem are defined in this paper on the basis of examination of scientific works of the $20^{\text {th }}-21^{\text {st }}$ centuries which deal with these multidimensional and complex categories. The research methodology was based on the theoretical method of systematization, which consists in the consideration of scientific theories of style and genre. This complex method presupposes a range of other methods: abstracting (in the differentiated examination of the notions of «style» and «genre» and extraction of their peculiarities); analysis (in making connections between the categories of style and genre); synthesis (in analysis of style 
and genre as the components of hierarchic system of music). Moreover, the historical method was also applied in the research (in the revelation of the character of style and genre correlation in the process of evolution of the musical thought). The scientific novelty of the work consists in articulating the problem of style and genre correlation, defining its significant theoretical aspects, developing theoretical discourse of style-genre nature of musical phenomena. Conclusions. It was demonstrated that style and genre correlation is determined by the logic of musicalhistorical process. The main theoretical aspects of the problem of correlation between these categories were defined: hierarchic subordination of genre to style, dialogical character of coexistence of style and genre, the phenomenon of genre style.

Key words: style, genre, correlation of style and genre, dialogue of style and genre, genre style, epochal style, individual style.

Вступ. Стиль і жанр - дві універсальні мистецтвознавчі категорії, без яких неможливе пізнання будь-якого художнього явища або процесу. Стиль у загальному розумінні є проявом характеру творчого мислення, жанр організацією вираження цього характеру, які реалізуються в художньому творі - матеріальній субстанті творчості.

M. Арановський справедливо відзначав, що стиль $\mathrm{i}$ жанр належать до розряду «вічних» і невичерпних тем у мистецтві, які з часом не тільки не втрачають, а й набувають актуальності [1, с. 13]. Думка вченого підтерджується наявністю різноманітних теорій стилю та жанру, створених упродовж XX ст., а також, альтернативними науковими пошуками сьогодення, викликаними істотними змінами в історичному й географічному просторі культури: поліфонізацією мистецтва, переосмисленням художніх традицій минулого, багатством національно-культурних діалогів. Відповідно, актуальність проблем стилю та жанру пов'язана із ключовим значенням цих категорій у мистецтві різних епох та дискусійним характером їхнього дослідження, зумовленим широким смисловим діапазоном кожного з цих понять, який охоплюе естетичні, соціокультурні, семантичні та психологічні характеристики.

Багатоаспектну проблематику стилю і жанру складають естетичні та логічні дефініції цих понять, питання етимології, генезису, функцій, морфології, стилістики та історичної типології, які найбільш плідно досліджувалися в естетиці, літературознаветві та культурології. Теоретичні положення праць М. Бахтіна, О. Лосєва, Г. Поспєлова, А. Сохора, С. Аверінцева, М. Кагана, О. Кривцуна, в яких у різний час порушувалися ці проблеми, становлять загальну методологічну основу мистецтвознавчого аналізу.

Теорії музичного стилю й жанру еволюціонували впродовж ХХ ст. у двох диференційованих площинах: теоретичній та історичній, причому в різний час домінував певний напрям дослідження. Так, на ранньому етапі (кін. XIX - пер. 
пол. ХХ ст.) простежусться розвиток історичного музикознавства. Концепції історичної типології музично-художніх епох, висунуті в той час у роботах Г. Адлера, Х. Рімана, П. Г. Ленга та Б. Яворського, визначили універсалізм понять стилю і жанру в контексті історичної еволюції музичного мистецтва.

У середині та другій пол. ХХ ст. в музикознавстві активно розроблялися теоретичні системи стилю і жанру, представлені Г. Бесселером, В. Цуккерманом, М. Михайловим, Л. Мазелем, А. Сохором, С. Назайкінським, М. Арановським, О. Соколовим, В. Медушевським, Н. Горюхіною, а в пізніший час-сучасними дослідниками М. Лобановою, В. Сировим, В. Холоповою, С. Шевляковим, I. Коханик, В. Москаленком. Кожна 3 цих теорій - авторська конщепція морфологічної будови музики, в якій розглядаються різноманітні властивості, ознаки та функції стилю або жанру.

У процесі грунтовного вивчення стилю i жанру перед науковцями невідворотно виникала проблема співвідношення цих категорій, але в жодній із праць ій не було приділено окремої уваги. Актуальність цієї проблеми особливо зростає в наш час, позначений «монологізацією свідомості» [2, с. 110], коли стиль і жанр дедалі втрачають свої автономні функції, розчиняючись в музичному творі - граничному вияві індивідуалізації художнього мислення. Відповідно, з розмиттям кордонів стилю і жанру акгивізуеться характер взаємодії цих категорій, що зумовлюс необхідність дослідження означеної проблеми.

Мета статті - на підставі вивчення і систематизації теорій стилю та жанру XX-XXI ст., виокремити проблему співвідношення цих категорій, виділити й висвітлити їі теоретичні аспекти, розкрити характер співвідношення стилю і жанру.

Одним із перших, хто відзначав факт взаємодії музичного стилю і жанру, був М. Михайлов, на думку якого «стиль не може існувати без тих жанрів, через які він знаходить вираження. Аналогічно жанри неможливо уявити поза їхньою конкретною реалізацією» $[4$, с. 80$]$. У той же час учений підкреслював панівну роль категорії стилю по відношенню до жанру, вважаючи функцію жанру «обмеженою, підпорядкованою провідним, більш загальним закономірностям розвитку мистецтва загалом» [4, с. 102]. Найбільш сконцентровано ця сентенція була сформульована М. Михайловим 3 огляду на закономірність музично-історичного процесу: «якщо стильова еволюція є одним із проявів цього [мистецького - О. Лігус.] розвитку, то еволюція жанрів виявляеться результатом стильової еволюції» [4, с. 102].

Нерозривний зв'язок стилю і жанру відзначався також музикознавцями наступних поколінь: С. Назайкінським, В. Медушевським, М. Лобановою, О. Самойленко, В. Сухащщевою. Так, Є. Назайкінський писав: «до проблем стилю у великій мірі належить і все те, що стосується музичних жанрів» [6, с. 79]. 
Однак, на відміну від теорії М. Михайлова, в якій визначено першорядність категорії стилю по відношенно до жанру, згадані дослідники схиляються до розуміння стилю і жанру як рівнозначних формотворчих універсалій різного ступеня узагальнення. У їніх працях чітко простежується тенденщія розглядати ці корелятивні поняття скоріше на рівні діалогу, ніж у межах ісрархічної залежності. Зокрема, проблему діалогу стилю і жанру в музиці досліджувала О. Самойленко [7], яка за відправну ідею взяла теорію діалогу М. Бахтіна. Згідно 3 цією теорією, розвиток і збагачення культури відбувається завдяки діалогічному обміну так званих «співрозмовників» - ключових категорій творчого процесу, серед яких особлива роль належить, власне, стилеві та жанру. Спираючись на концешію російського вченого, О. Самойленко визначила характер взаємодії музичного стилю i жанру аналогічно співвідношенню різних, але пограничних понять: символіки і семантики, «авторитарності» i «переконливості», «естетичного» та «етичного» [7, с. 4, 11].

Взаємодію стильового і жанрового начал відображає і феномен «жанрового стилю», уперше вжитий і охарактеризований А. Сохором. Цей учений розумів жанровий стиль із погляду первинних жанрів, вбачаючи в ньому «систему засобів виразності, що вирізняється самобутністю та внутрішньою цілісністю (які зумовлені своєрідністю та цілісністю змісту)» [9, с. 296]. Серед основних критеріїв жанрового стилю дослідник виділив характерний для певного жанру ритм, тип мелодики і специфіку фактури, які визначаються, за його словами: «як типовим змістом жанру, так і безпосередньо його життєвим призначенням» [9, с. 297], тобто, жанровим змістом і жанровою ситуацісю.

Пізніпе термін «жанровий стиль» трактувався музикознавцями порізному: від його розуміння на рівні типізації жанрового змісту, семантичних ознак і жанрової ситуації - до рівня індивідуалізації жанру. Так, М. Михайлов ототожнював поняття жанрового стилю i «жанрового змісту», тим самим поставивши під сумнів правомочність позиції А. Сохора. Відповідно, вчений відносив жанровий стиль до «окремішньої стилістичної сфери, що поєднує специфічні ознаки жанру з ознаками інших, більш об' ємних стильових систем, від яких вона залежить» [4, с. 97].

Інша відмінність трактування жанрового стилю (жанрового змісту) М. Михайловим від А. Сохора полягала в тому, що М. Михайлов намагався пояснити це явище в контексті композиторської творчості, тобто вторинних жанрів. При цьому, дослідник підкреслював невідворотність впливу індивідуального творчого задуму на жанровий зміст: «Чим яскравішою $є$ творча індивідуальність композитора, тим сильнішою виявляеться й індивідуалізація жанру в значенні «жанрового змісту». I навпаки, типові жанрові ознаки виразніше виступають у тих творах, що позбавлені яскравого вираження 
авторської особистості» [4, с. 95]. Подібні міркування висловив і С. Назайкінський: «Чим більше віддалясться той чи інший жанр від своїх первинних умов буття, тим інтенсивніше він освоюється як відображений, вторинний, тим вагомішими стають його суто музичні прояви, тобто те, що якраз розуміється жанровим стилем» [6, с. 150].

Оригінальне трактування жанрового стилю запропонував Ю. Созанський [8]. Він розглядав це явище у співвідношенні із синонімічними (на його думку) поняттями «жанровий синтаксис», «асоціації через жанр», «узагальненням через жанр» 3 метою систематизації елементів семіотичної моделі інструментальної музики. Проаналізувавши чисельну низку творів різних інструментальних жанрів (симфонії, програмної увертюри, симфонічної поеми, фортепіанної мініатюри), вчений виділив «жанровий стиль» та «асопіації через жанр» як дві узагальноючі категорії ієрархічної системи елементів семіотичної моделі.

Диференціюючи обидва поняття, які є функціонально близькими одне до одного, Ю. Созанський довів, що жанровнй стиль - це елемент субстратний, тоді як асоціації через жанр - атрибутивний. У формулюванні визначень обох категорій дослідник спирався на інтелектуальний досвід із галузі сучасних комп'ютерних технологій. Таким чином, жанровий стиль за Ю. Созанським, це набір параметрів форматування (формотворення), який застосовується до музичного тексту для того, щоб однісю дісю змінити одразу всю групу атрибутів форматування, характерного для певного жанру, тоді як асоціації через жанр є продуктом фантазії слухача, що виникає як реакція на сприйняті в музичному творі структури жанрового стилю (структури певного жанрового синтаксису).

У наукових розробках останнього десятиліття спостерігається тенденція трактування жанрового стилю на рівні індивідуального стилю. Так, В. Москаленкові, який досліджує проблеми інтерпретації у стильовому та жанровому контексті, належить термін «жанрово-творчої ситуації», яка, на його думку, виникає внаслідок осмислення композитором чи інтерпретатором «надособистісного» інтонаційного потенціалу відповідного музичного жанру» [5, с. 81]. Виходячи 3 цього, можна сказати, що жанрово-творча ситуація є основною умовою виникнення жанрового стилю.

Згодом концепцію В. Москаленка взяла за основу I. Тукова, яка вивчала феномен жанрового стилю в контексті жанрово-творчої ситуації [11]. Аналізуючи шлях історичної еволюції жанру, який, за М. Арановським, являс собою рух від 
жанрових варіантів - до жанрового інваріанту (сталої моделі жанру), і надалі знову до жанрового варіювання, дослідниця визначила, що саме на останньому етапі, коли «установка на типізацію змінюеться установкою на індивідуалізацію» [11, с. 29], і відбувається формування жанрового стилю. Також I. Тукова визначила необхідні підстави для виникнення жанрового стилю:

- наявність у творчості композитора «монографічного» жанру (до якого часто звертається композитор), в якому типізовані жанровий зміст та характерна жанрова семантика;

- набуття жанром «авторського шару», що вказуе на знаковість цього жанру в контексті жанрової еволюції як результату індивідуальної творчості композитора.

Таким чином, особливості взаємодії жанру і стилю багато в чому обумовлоються історичним розвитком музичного мислення. Якщо в музиці давніх епох детермінантою стилю та жанру був канон, то 3 часом індивідуалі-зація творчого вираження привела до втрати кожною категорісю свосї автономії. Вершиною втілення індивідуального начала в координатах стилю і жанру стало явище «жанрового стилю».

Наукова новизна роботи полягає в порушенні проблеми співвідношення стилю і жанру, в окресленні ї основних теоретичних аспектів, у розвитку теоретичного дискурсу стиле-жанрової природи музичних явищ.

Висновки. Незважаючи на беззаперечний факт автономності та самодостатності як стилю, так і жанру, неможливо оминути проблему їх співвідношення, адже ці категорії складають пару нерозривно пов'язаних іманентних граней поетики, взаємодією яких живиться історико-художній процес. За влучним висловом В. Суханцевоі, «в музичній культурі відбувається нескінчена процедура стиле-жанрових взаємодій, завдяки чому музика уникає статичності, скам'янілої історії, тощо» [10, с. 141].

На підставі вивчення наукових праць ХХ-XXI ст. (М. Михайлова, А. Сохора, С. Назайкінського, В. Медушевського, М. Лобанової, Ю. Созанського, В. Москаленка, О. Самойленко, В. Суханцевої, І. Тукової), присвячених цим складним багаторівневим поняттям, було виділено основні теоретичні аспекти проблеми співвідношення цих категорій: ієрархічну підпорядкованість жанру стилеві; діалогічний характер співіснування стилю і жанру; феномен жанрового стилго.

Осмислення процесу співвідношення стилю і жанру в означених аспектах дало можливість визначити також історичний вектор дослідження цієї проблеми. Упродовж еволюції музнчного мислення простежується істотне переосмислення категорій стилю і жанру: від їх чіткої автономії - до тісної взаємодії та взаємопроникнення, найвищим вираженням якого є феномен «жанрового стилю» в його сучасному трактуванні. 


\section{Список використаних джерел}

1. Арановский М. Г. Концепция музыкального стиля в работах М.К. Михайлова / М. Г. Арановский // Этюды о стиле в музыке : статьи и фрагменты. - Ленинград : Музыка, 1990. - С. 13-38.

2. Лобанова М. Н. Музыкальный стиль и жанр: история и современность / М. Н. Лобанова. - Москва : Сов. Композитор, 1990. - 312 с.

3. Медушевский В. В. Музыкальный стиль как семиотический объект // Советская музыка. - 1979. - № 3. - С. $30-39$.

4. Михайлов М. К. Стиль в музыке: исследование / М. К. Михайлов. Ленинград : Музыка, 1981. - $264 \mathrm{c}$.

5. Москаленко В. Г. Творческий аспект музыкальной интерпретации (к проблеме анализа). Исследование. / В. Г. Москаленко. - Киев : КГК, 1994. $157 \mathrm{c}$.

6. Назайкинский E. В. Логика музыкальной композиции / Е. В. Назайкинский - Москва : Музыка, 1982. - 319 с.

7. Самойленко А. Стиль как музыкально-культурологическая категория в свете теории диалога М. Бахтина / О. Самойленко // Науч. Вестн. Нац. Муз. Акад. Украины имени. П. І. Чайковского. Муз. стиль: теорія, історія, современность. - Киев, 2004. - Вип. 37. - С. 3-13.

8. Созанський Ю. С. Музична семіотика / Ю. С. Созанський. - Львів : Сполом, 2008. - $522 \mathrm{c}$.

9. Сохор А. Н. Теория музыкальных жанров: задачи и перспективы / А.Н. Сохор // Теоретические проблемы музыкальньх форм и жанров. Москва, 1971. - С. 292-310.

10. Суханцева В. К. Музыка как мир человека. От идеи вселенной к философии музыки / В. К. Суханцева. - Киев : Факт, 2000. - 176 с.

11. Тукова И. О понятии «жанровый стиль» / І. Тукова // Науч. Вестн. Нац. Муз. Акад. Украины имени. П. І. Чайковекого. Муз. стиль: теорія, історія, современность. - Київ, 2004. - Вип. 38. - С. 27-33.

\section{References}

1. Aranovskiy, M.G. (1990). Conceptions of Musical Style and Genre in the Works by M.K. Mihaylov. Etyudy o stile v muzyke: Stat'i i fragmenty [Mihaylov M. The Etudes about Style in Music: Articles and Fragments], pp. 13-38.

2. Lobanova, M.N. (1990). Musical Style and Genre: History and Modernity. Moskow: Sovetskii Kompozitor.

3. Medushevskiy, V.V. (1979). Musical Style as a Semiotic Object. Sovetskaya muzyka [Soviet Music], no. 3, pp. 30-39.

4. Mihaylov, M.K. (1981). Style in Music: Research. Moskow: Muzyka. 
5. Moskalenko, V.G. (1994). Creative Aspect of Musical Interpretation (to the Problem of Analysis). Research. Kyiv: Kievskaya gosudarstvennaya konservatoriya.

6. Nazaykinskiy, E.V. (1982). Logics of Musical Composition. Moskow: Muzyka.

7. Samoylenko, A. (2004). Style as a Musical and Culturological Category in the light of M. Bakhtin's Theory of Dialogue. Nauchnyi Vestnik Natsional'noi Muzykal'noi Akademii Ukrainy imeni. P. I. Chaikovskogo. Muzykal'nyj stil': teorija, istorija, souremennost' [Scientific Joumal of Petro Tchaikovsky National Music Academy of Ukraine. Style of Musical Creativity: Aesthetics, Theory, and. Performance], issue 37 , pp. 3-13.

8. Sohor, A.N. (1971). Theory of Musical Genres: Challenges and Prospects. Teoreticheskie problemy muzykal'nyh form $i$ zhanrov [Theoretical Problems of Musical Forms and Genres], pp. 292-310.

9. Sozanskyi, Yu.S. (2008). Musical Semiotics. Lviv: Spolom.

10. Suhanceva, V.K. (2000). Music as a World of Human. From the Idea of the Universe to the Philosophy of Music. Kiev: Fakt.

11. Tukova, I. (2004). To the Concept of the Genre's Style. Nauchnyi Vestnik Natsional'noi Muzykal'noi Akademii Ukrainy imeni. P. I. Chaikovskogo. Muzykal'nyj stil': teorija, istorija, sovremennost' [Scientific Journal of Petro Tchaikovsky National Music Academy of Ukraine. Musical Style: Theory, History and Modernity], issue 38 , pp. $27-33$.

$\overline{\text { (C) Jizyc O.M., } 2016}$ 